\title{
DEMOGRAPHIC RESPONSE TO ACCESSIBILITY IMPROVEMENT IN DEPOPULATION CROSS BORDER REGIONS: THE CASE OF EUROREGION DANUBE 21 IN SERBIA
}

\author{
Ana Vulević* ${ }^{*}$, Aleksandar Knežević ${ }^{* *}$ \\ "Institute of Transportation CIP, Belgrade \\ *University of Belgrade - Faculty of Geography, Belgrade
}

\begin{abstract}
This paper analyses the relationship between the accessibility improvement and demographic pattern in the border region of Euro region Danube 21 in Serbia. In many CBC projects accessibility has been identified as a key factor for their territorial success. But according to the European Spatial Planning Observation Network (ESPON) project and strategies, accessibility patterns are strongly associated with dynamic population pattern in border areas. The demographic challenges that some cross-border areas are facing are structural and permanent. Therefore the paper evaluated and assessed demography factors as the main factors in accessibility analyses in this depopulation cross-border area. The article includes key messages for policy-makers for transportation designing and implementing development transportation strategies specifically tailored to the needs of these regions.
\end{abstract}

Key words: depopulation, cross border regions, accessibility, demographic pattern, Serbia.

${ }^{1}$ Corresponding author: A. Vulević, Institute of Transportation CIP, Nemanjina 6/IV, 11,000 Belgrade, Serbia; e-mail: vulevica@sicip.co.rs 


\section{Introduction}

Many CBC Projects, between EU boundaries, also demonstrate an example of the success of cross-border cooperation (LISER, 2015). Based on the newer studies and research (see: Castanho et al., 2016; Nicolini and Pinto, 2013; Vulević, 2013; Dominguez Castro and Varela Alvarez, 2015; Kurowska-Pysz, 2016; among many others), critical factors for territorial success have already been identified. According to researchers, planners, and decision makers, regarding $\mathrm{CBC}$ Projects the promotion of accessibility is one of the most significant factors (Castanho et al. 2017).

The fact is that the accessibility measures in border regions of all the European countries seem to be much lower than the internal accessibility measures. It can be explained by two factors: the density of cities in border regions is usually lower than in the interior of a country, and accessibility in border regions is lower due to the lower density of transportation infrastructure in these locations. Another important fact is the low accessibility on the peripheries of Europe, especially in the east regions, where Euro region Danube 21 belongs.

Euro region Danube 21 encompasses urban and rural regions from the riverine areas of the Danube in Romania, Bulgaria and Serbia. The objective of the cooperation under this format is to solve some common issues which these areas, situated at a large distance from the administration centres, have to cope with. Serbian part of this Euro region belongs to underdeveloped, economically and demographically depressed regions; region of Pan-European Transport Corridor 7 (the Danube with partly used navigability potential and unused nautical potential) and contact area between the Pan-European Corridor 10 to the west and Corridor 4 to the east. The position of Euro region between multimodal corridors X, VII and IV enables its transitional role and development, once they connect with the missing transversely and longitudinally road directions. Since the late 1990s, a series of European policy documents such as: the European Spatial Development Perspective (1999), the White Paper for the EU Transport Policy and midterm review (2001 and 2006), "Enlargement strategy and main challenges" (2007) and the Green Paper on Territorial Cohesion (2008) refer to the "peripheral" position of South-East Europe and the need of improving accessibility and mobility conditions in order to achieve spatial integration and socio-economic cohesion (Vickerman et al. 1997; Pitsiava 2007). The ESPON Programme also calls for a more balanced and polycentric development in CBC area (ESPON - ITAN - Integrated Territorial Analysis of the Neighborhood, 2015). Losch (1994) described border regions as deserts, as wastelands 
in which many products only can be obtained from distance or not at all. According to van Houtum (2000), border regions are generally regarded as marginal spaces disadvantaged by their peripheral locations and divided market areas resulting in limited possibilities for economies of scale. Spiekermann and Wegener (1996) have observed the phenomenon in the study of accessibility - it is expected that these border problems associated with measures of accessibility should become less severe, getting the crowd into account when calculating the travel time, but they would not disappear.

There is no universally acknowledged definition of accessibility. Various indicators with different complexity have been proposed and implemented in empirical investigations (see, e.g., Ingram 1971; Morris et al.1978; Handy, Niemeier 1997). Accessibility is commonly defined as the ease with which activities can be reached from a certain place and with a certain system of transportation (Morris et al. 1979; Johnston et al. 2000). The concept generally takes the combination of two elements into account: the location on a surface relative to suitable destinations, and the characteristics of the transportation network (Vickerman 1974). Comprehensive literature on academic measures of accessibility indicates that there are many ways in which to define and quantify the accessibility and these have broadly enriched the theoretical understanding of the accessibility of getting more and more components into account: spatial, economic, demographic, and social. The regional demographic development is a complex process which is conditioned by the components of population dynamics, both the natural increase (through birth and death) and the migrations, as well as by the changes in demographic structures. Between the number of population and the population structures exists the mutual interrelation (Breznik 1989). Natural and mechanical movement of population depends on the population age structure in a particular region, but also conditions the future age structure. Since the current tendency appears to be the decrease of European population, followed (and partly caused) by gradual ageing of the community as a whole, the demographic components have recently become an important subject of public and political debates in various European countries and regions. These debates are mostly oriented towards defining of the present and future problems generated as a consequence of the population decline, that is, as a consequence of the decline in population density. Therefore, it appears there is a need for infrastructure adjustment, especially in sparsely populated regions, as well as the need for keeping the minimal standards of regional infrastructure. Besides the above mentioned, the question has been raised related to expenditures and needs of the ageing population. 
Accordingly this paper focuses on one particular aspect of border population accessibility and the general perception of accessibility of this area which is, to a considerable extent, shaped by trends in population, as well as with structural changes in the border area of Serbian side of Euro region Danube 21. Conventional planning tends to overlook and undervalue some of these factors and perspectives. Because of that, Demographic Analysis aims to identify the key factors of depopulation process and explain that the depopulation would not disappear related to the improvement of accessibility in subject area.

The Paper also aims to formulate hypotheses for answering the questions, such as: Is the level of accessibility in border regions lower than in central regions? Can the accessibility improvement lead to stopping depopulation process in this area? Is the population of the border region growing faster or slower than non-border and central regions? Is the population of the border region ageing more or less rapidly than in non-border regions? To answer the above questions this paper considers and discusses the link between dynamic population patterns and the way regional planners and practitioners can define transportation problems and evaluate potential solutions by including additional demographic factors in Euro region Danube 21 and in border regions with similar problems.

\section{Demography and accessibility in ESPON projects, national spatial plan and strategies}

The aim of the ESPON Programme DEMIFER - Demographic and migratory flows affecting European regions and cities (2008-2010) is to assess future changes in population growth, the size of the labour force and the ageing of the population, and to explore different policy options aiming at regional competitiveness and territorial cohesion. Assessing the impact of intra-Europe and extra-Europe depopulation and migration on population dynamics were main tasks in this endeavour. In this regard ESPON Project ULYSSES (Using applied research results from ESPON as a yardstick for cross-border spatial development planning, 2013) is an experimental and innovative project supported by 18 European CBC areas, which applied results from ESPON as a yardstick for decentralized cross-border development planning. A territorial profile refers to indicators of the five major ESPON themes: polycentric development; urban-rural relationship; accessibility, connectivity and demography. The territorial performance refers to their potential to achieve 
Lisbon/EU 2020 and Gothenburg strategy goals. The indicators of each CBC area were compared on different scales, (NUTS3 - NUTS2; cross-border areas and countries), through a reference index that can be established by the EU27 average (leading region in the EU27 they belong).

The ESPON scientific platform encompasses various methodologies for carrying out the spatial analysis and analysis of influence, the key indicators, but also the ESPON database and the tools for mapmaking. Furthermore, there is a need for a more concise overview of the condition in European regions, and a key for interpreting the results consisting of new method developed by ESPON, Regional Classification of Europe (RCE). The following thematic fields of the RCE were elaborated throughout: Economy, Labour Market, Lisbon Performance, Demography, Naturalness, Hazards, and Accessibility. The essential idea of this concept is the establishment of combined indicators for series of thematic fields based on adding combinations of individual indicators. Combined accessibility analysis is the only analysis in which the traditional pattern of relationships between the centre and the periphery is clearly visible. The quantity and the quality of the existing regional infrastructure, as well as the distance (time of travelling), the population or/and the economic centres play the important role in it. Therefore, these indicators are believed to be prestigious for the list of national spatial indicators in Serbia as well. According to the National Spatial Plan of the Republic of Serbia 2010-2020, the methodology is applied based on the model of Regional classification of Europe, developed by ESPON. Considering the thematic field of Accessibility the selected accessibility indicators are the ones which reflect the equipment with the existing infrastructure at level NUTS 3 in Serbia. The final results in this thematic field are calculated by combination of five indicators, whereas the applied accessibility pattern clearly indicates the differences between central and peripheral regions.

Spatial patterns of accessibility - directed by transportation networks - are strongly associated with population distribution (Mun 1997; Kotavaara et al. 2011a; 2011b). The link between population distribution patterns and transportation networks remains an issue that still requires scrutiny (Gastner and Newman 2006). The differentiation between causes and effects is also taken into consideration in the separation of the thematic fields regarding e.g. "Demographic structure and development" in ESPON study. The indicators for this thematic field have been calculated by the combination of four indicators: the population density, the ageing (a share of population aged 65 years or over), the potential of natural increase and the number of population. 
The EU shall aim at reducing disparities between the levels of development of the various regions and the backwardness of the least favoured regions. Among the regions concerned, particular attention shall be paid to rural areas, areas affected by industrial transition, and regions which suffer from severe and permanent natural or demographic handicaps such as the northernmost regions with very low population density and island, crossborder and mountain regions" (Article 174 of Lisbon Treaty, 2017).In this regards, the ESPON Working Paper "Revealing territorial potentials and shaping new policies in specific types of territories in Europe", including map about changing of accessibility, 2014-2030, of all kind of transport and about demography change.

\section{Methodology approach}

The quantitative, comparative and statistical analysis methods are used in elaborating the present article. The emphasis of this paper is on the choice and the description of a set of demographic factors as main factors in accessibility analysis in border depopulation area. The research of long-term demographic changes and mutual influences between the accessibility of transport infrastructure systems and demographic potentials in Euro region Danube 21 were based on the official data of census and vital statistics. We evaluated the synthesis approach on considering long-term demographic changes, and elected the use of statistical data for the long period of time. For some of the indicators Census data from 1948 to 2011 has been used. In terms of the comparative method, the main results are represented at two territorial levels: the county/NUTS 3 (statistical unit size from 150.000 up to 800.000 population) - in accordance with the Regulation on Nomenclature of territorial units for statistics (Official Gazette RS, No. 109/09 and 46/10, Art. 5) and Euro region Danube 21 which we have in specific segments compared with demographic and accessibility indicators calculated at the level of Central Serbia.

In terms of the comparative method, the main results are represented at two territorial levels: the county/NUTS 3 and Euro region Danube 21 which have in specific segments been compared with demographic indicators calculated at the level of Central Serbia.

The values of accessibility levels for case counties of Euro region Danube 21 are collected from the National Spatial Plan of Republic of Serbia (20102021). Both road and railway modes of transportation were analysed, which is consistent with the existing use of these transport modes, within our bounda- 
ries, at the county level and regional level. We elected only the indicators of road and rail transport - the level of daily migrations. Data on length and density of both road and railway networks are published by the Statistical Office of the Republic of Serbia (2007) and show the present state of equipment with these modes of transportation infrastructure for case region. Comparative view of Census for the other years is not made, because the long-term considered differences in data on length and density of both road and railway networks have been negligible from 1996 to today. The final values of accessibility level, considering Euro region Danube 21 (Bor and Zaječar county) were compared with the accessibility results which have been calculated at the level of Central Serbia in the National Spatial Plan in Serbia (2010-2021).

The methodology was divided into three main phases, ending with the analysis and assessment of demographic situation related to the accessibility improvement. The phases are: data collection; selection criteria; case study analyse, as follows:

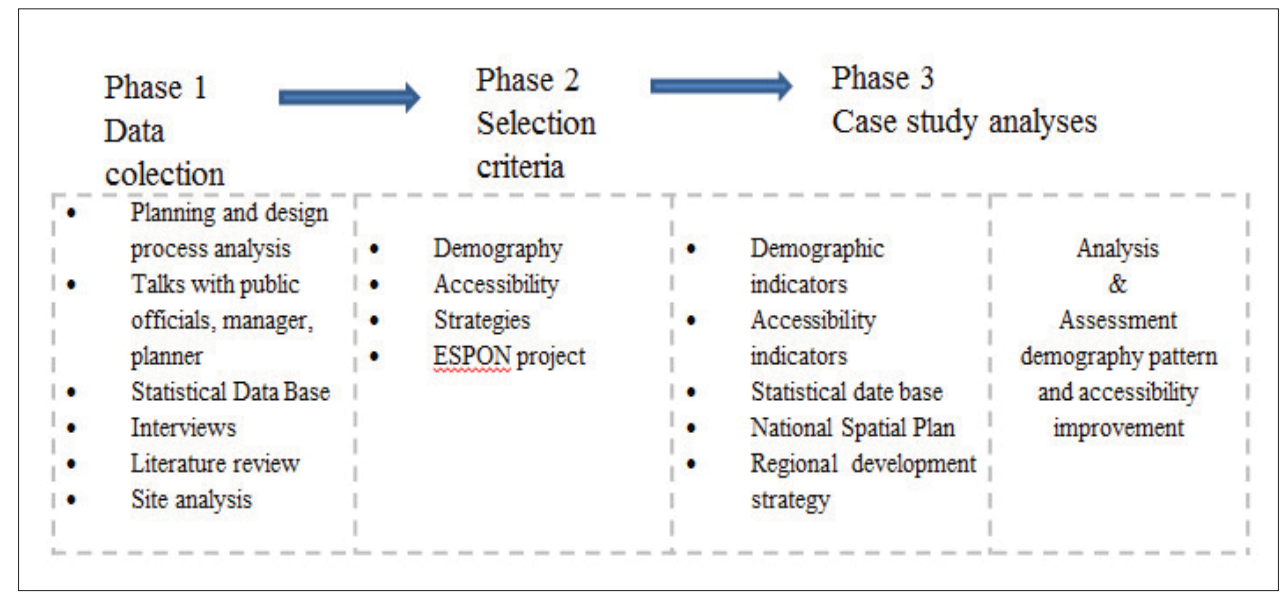

Figure 1 - Methodological approach

\section{Data analysis}

Spatial framework of the research in this paper is enclosed with Euro region Danube 21, which encompasses border region of the Republic of Serbia by sharing the border with Romania and Bulgaria, and which was formed in 2002 in Vidin as a part of project of European Union on cross-border coopera- 
tion across the countries of Central and Eastern Europe. It consists of 21 administrative units (which explains its name), whereas the territorial structure, as well as the way it was formed, indicate spatial-demographic disparity.

The biggest part of area Euro region Danube 21 (about 68\%) is situated in the territory of the Republic of Serbia where it encompasses both Bor county (municipalities Bor, Majdanpek, Kladovo and Negotin) and Zaječar county (municipalities Zaječar, Knjaževac, Boljevac and Sokobanja), where, according to 2011 Census data, lives about 244,959 inhabitants, that is, about $60 \%$ of the total number of inhabitants in this Euro region. Only about $10 \%$ of the territory and $10 \%$ of the population is situated in Romania, whereas about $22 \%$ of the territory and about $30 \%$ of the population is situated in Bulgaria. (Tošić, Stojanović, Miletić 2005; Bufon 2011; Knežević 2014; Knezević, Vojković 2015).

\section{Accessibility pattern in Euro region Danube 21 in Serbia}

Accessibility by road based on road transport accessibility and measurement of road network density.

Table 1 - Road network density - comparative view in the territory of the Republic of Serbia

\begin{tabular}{|c|c|c|c|c|c|c|}
\hline $\begin{array}{l}\text { County/ } \\
\text { NUTS3 }\end{array}$ & $\begin{array}{c}\text { Area } \\
\left(\mathbf{k m}^{2}\right)\end{array}$ & $\begin{array}{l}\text { Number of } \\
\text { population }\end{array}$ & $\begin{array}{l}\text { Roads } \\
\text { (a total) }\end{array}$ & $\begin{array}{c}\text { Modern } \\
\text { roadways } \\
\text { (a total) }\end{array}$ & $\begin{array}{c}\text { Network } \\
\text { density } \\
\left(\mathbf{k m} / \mathbf{k m}^{2}\right)\end{array}$ & $\begin{array}{c}\text { Network } \\
\text { density } \\
(\mathrm{km} / 1000 \\
\text { inhabitants) }\end{array}$ \\
\hline $\begin{array}{l}\text { Republic of } \\
\text { Serbia }\end{array}$ & 77,474 & $7,381,779$ & 15,808 & 14,392 & 0.2040 & 2.1414 \\
\hline Belgrade & 3,227 & $1,611,533$ & 1,003 & 975 & 0.3107 & 0.6222 \\
\hline $\begin{array}{l}\text { Central } \\
\text { County }\end{array}$ & 13,239 & $1,263,471$ & 2,888 & 2,594 & 0.2181 & 2.2854 \\
\hline Bor County & 3,510 & 136,437 & 765 & 707 & 0.2179 & 5.6070 \\
\hline $\begin{array}{l}\text { Zaječar } \\
\text { County }\end{array}$ & 3,623 & 128,056 & 751 & 640 & 0.2073 & 5.8646 \\
\hline
\end{tabular}

Source: Statistical Office of the Republic of Serbia (2007).

Accessibility by railroad based on length of the railroad and railroad network density measurement. 
Table 2 - Accessibility by railroad - Length and density of the railway network

\begin{tabular}{|c|c|c|c|c|c|}
\hline $\begin{array}{l}\text { County/ } \\
\text { NUTS3 }\end{array}$ & $\begin{array}{r}\text { Area } \\
\left(\mathbf{k m}^{2}\right)\end{array}$ & $\begin{array}{l}\text { Number of } \\
\text { Population }\end{array}$ & $\begin{array}{l}\text { Lenght of } \\
\text { the railroad } \\
\text { network } \\
\text { (km) }\end{array}$ & $\begin{array}{c}\text { Density of } \\
\text { the railroad } \\
\text { network } \\
\left(\mathrm{km} / \mathrm{km}^{2}\right)\end{array}$ & $\begin{array}{c}\text { Density of } \\
\text { the railroad } \\
\text { network } \\
\text { (km/1000 } \\
\text { inhabitants) }\end{array}$ \\
\hline Belgrade & 3,227 & $1,611,533$ & 307,010 & 0.10 & 0.19 \\
\hline Borski & 3,510 & 136,437 & 104,544 & 0.03 & 0.77 \\
\hline Zaječarski & 3,623 & 128,056 & 102,072 & 0.03 & 0.80 \\
\hline Central Serbia & 12.266 & $1,263,471$ & 464,85 & 0.38 & 0.40 \\
\hline
\end{tabular}

Source: Spatial Plan of Republic of Serbia and Statistical Office of the Republic of Serbia (2007)

Accessibility indicator the 30-minutes isochrones time to market calculated on the basis of adopted speeds the 30-minutes isochrones are determined, whereas the time to market is measured by the number of inhabitants within the 30-minutes isochrones.

Table 3 - Number of inhabitants within the 30-minute isochrone.

\begin{tabular}{|l|c|c|}
\hline $\begin{array}{l}\text { The Centers of the County/ } \\
\text { NUTS 3 }\end{array}$ & Area/km ${ }^{\mathbf{2}}$ & $\begin{array}{c}\text { Number of population } \\
\text { (2002) }\end{array}$ \\
\hline Beograd & 3,625 & $1,691,098$ \\
\hline Zaječar & 2,427 & 137,812 \\
\hline Bor & 1,874 & 117,592 \\
\hline
\end{tabular}

Source: Spatial Plan of the Republic of Serbia 2010-2014-2020

Travel time to the nearest regional centres based on accessibility by road which represents the average travel time to the nearest regional centres - Novi Sad, Kragujevac and Niš.

Table 4 - Travel time to two or three nearest regional centres (denoted by minutes)

\begin{tabular}{|l|c|c|c|c|}
\hline The centers of the County/ NUTS 3 & Novi Sad & Belgrade & Kragujevac & Nis \\
\hline Zaječar & 240 & 167 & 164 & 89 \\
\hline Bor & 237 & 171 & 128 & 107 \\
\hline
\end{tabular}


The final accessibility results in National Spatial Plan of Serbia, calculated on the basis of values of indicators are classified into categories: well below the average, below the average, the average, above the average and well above the average. The existing accessibility pattern indicates significant differences between the central and the peripheral counties in Serbia. Peripheral counties are given the scores below the average considering almost all indicators. The values for Bor County and Zaječar County are the lowest ones considering all indicators, which put these districts into accessibility category - well below the average in Serbia.

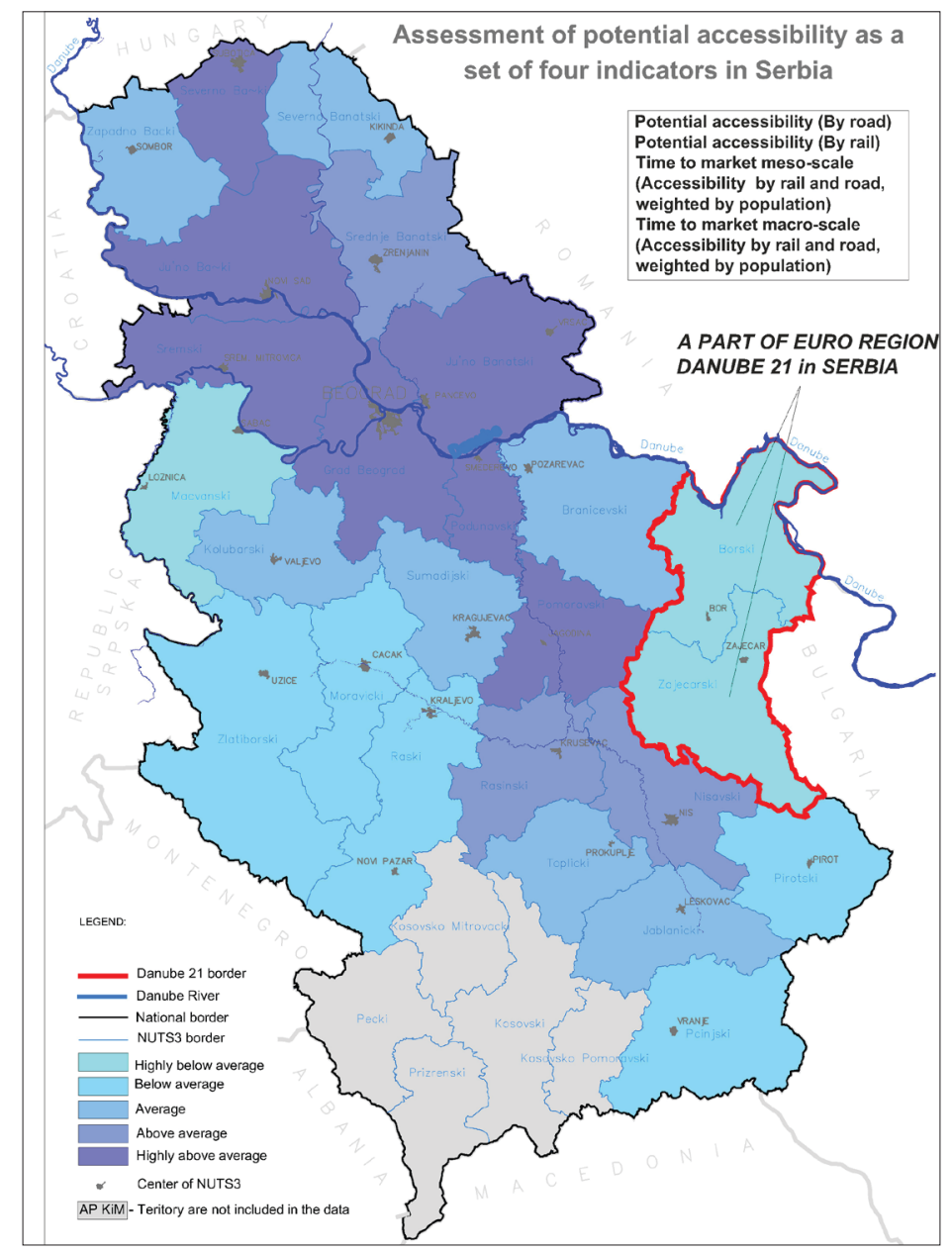

Figure 2 - Assessment of accessibility as a set of four indicators in Serbia Source: National Spatial Plan of Serbia 2010-2020 


\section{The selection of demographic factors}

\section{Dynamics in number of population in Danube 21 Euro region}

Dynamics in the number of population in Danube 21 Euro region for the period of 1948-2011 is characterized by gradual population increase to the eighties of the 20th century, when it has started the depopulation process and which has been particularly intensified through the last census in between period, whereas already in 1991 the total number of inhabitants was smaller than at the beginning of observation period in 1948.

Table 5 - The number of population in Danube 21 Euro region for the period of 1948-2011

\begin{tabular}{|c|c|c|c|c|c|}
\hline \multirow{2}{*}{ Danube21 } & \multicolumn{2}{|c|}{ Bor County } & \multicolumn{2}{c|}{ Zajecar County } \\
\cline { 3 - 6 } & & number & $\mathbf{0}$ & number & \% \\
\hline 1948 & $\mathbf{3 1 7 , 6 5 2}$ & $\mathbf{1 4 4 , 0 4 9}$ & 45.3 & $\mathbf{1 7 3 , 6 0 3}$ & 54.7 \\
\hline 1953 & $\mathbf{3 2 9 , 3 0 5}$ & $\mathbf{1 5 1 , 9 7 3}$ & 46.1 & $\mathbf{1 7 7 , 3 3 2}$ & 53.9 \\
\hline 1961 & $\mathbf{3 3 8 , 7 1 9}$ & $\mathbf{1 6 0 , 0 9 6}$ & 47.3 & $\mathbf{1 7 8 , 6 2 3}$ & 52.7 \\
\hline 1971 & $\mathbf{3 4 8 , 2 7 2}$ & $\mathbf{1 7 5 , 8 4 8}$ & 50.5 & $\mathbf{1 7 2 , 4 2 4}$ & 49.5 \\
\hline 1981 & $\mathbf{3 5 1 , 1 4 5}$ & $\mathbf{1 8 0 , 4 6 3}$ & 51.4 & $\mathbf{1 7 0 , 6 8 2}$ & 48.6 \\
\hline 1991 & $\mathbf{3 1 7 , 4 0 5}$ & $\mathbf{1 6 3 , 2 2 9}$ & 51.4 & $\mathbf{1 5 4 , 1 7 6}$ & 48.6 \\
\hline 2002 & $\mathbf{2 8 4 , 1 1 2}$ & $\mathbf{1 4 6 , 5 5 1}$ & 51.6 & $\mathbf{1 3 7 , 5 6 1}$ & 48.4 \\
\hline 2011 & $\mathbf{2 4 4 , 9 5 9}$ & $\mathbf{1 2 4 , 9 9 2}$ & 51.0 & $\mathbf{1 1 9 , 9 6 7}$ & 49.0 \\
\hline
\end{tabular}

Source: P3C (2004), P3C (2011).

According to results from the last conducted census in 2011 in Serbia the overall decline in number of population in Euro region in comparison to the 1948 equalled nearly $23 \%$, or 72,693 inhabitants. It is evident that the depopulation process more rapidly occurred in Zaječar County where already during the sixties was recorded the population drop. For the overall period the population of Danube 21 Euro region has been going down according to the average year rate of $-4.1 \%$, where as in Bor County the population decreased with nearly $13 \%$, and in Zaječar County with $31 \%$. 


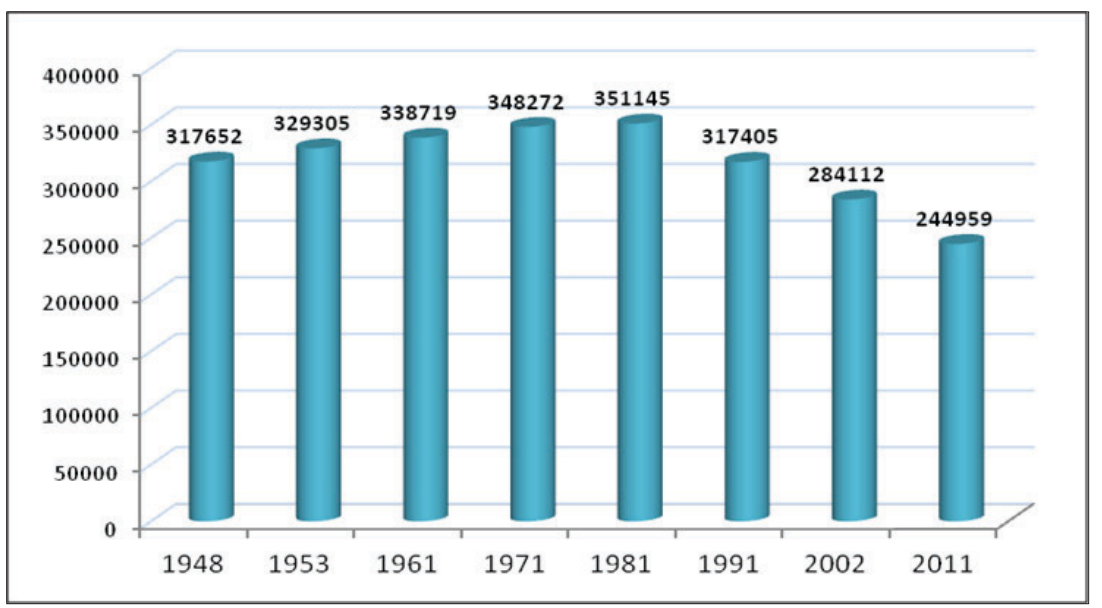

Figure 3 - Trend in the number of population of Euro region Danube 21 in Serbia, 1948-2011

Table 6 - Population growth indicators in Danube 21 Euro region for the period of 1948-2011.

\begin{tabular}{|l|c|c|c|c|}
\hline & $\begin{array}{c}\text { Population } \\
\text { growth }\end{array}$ & $\begin{array}{c}\text { Average } \\
\text { annual } \\
\text { growth }\end{array}$ & $\begin{array}{c}\text { Rate of } \\
\text { average } \\
\text { annual } \\
\text { growth }\end{array}$ & $\begin{array}{c}\text { Index of } \\
\text { growth }\end{array}$ \\
\hline Danube 21 & $-72,693$ & $-1,154$ & -4.1 & 77.1 \\
\hline Bor County & $-19,057$ & -302 & -2.2 & 86.8 \\
\hline Zaječar County & $-53,636$ & -851 & -5.8 & 69.1 \\
\hline
\end{tabular}

Source: Estimation based on the data from the Table 5.

Population distribution and population density in Danube 21 Euro region

A huge fragmentation of settlements brings the main feature of the present settlement network in Danube 21 Euro region. Overall 263 settlements are situated in the area of $7,130 \mathrm{~km}^{2}$ between two areas (Bor and Zaječar) which comprise overall 8 municipalities. From eight mentioned municipalities, according to administrative criteria as for the municipality settlement classification, three municipalities (Kladovo, Majdanpek and Boljevac) contain two urban settlements, whereas the remaining municipalities comprise one urban settlement each one. 
Demographic Response to Accessibility Improvement in Depopulation Cross Border Regions: The Case of Euroregion Danube 21 in Serbia

Table 7 - The surface, the number of settlements and population density of Danube 21 Euro region in Serbia

\begin{tabular}{|l|c|c|c|}
\hline & Area $\left.\mathbf{( k m}^{\mathbf{2}}\right)$ & $\begin{array}{c}\text { Number of } \\
\text { settlements }\end{array}$ & $\begin{array}{c}\text { Density } \\
\text { inhabit./ } \mathbf{k m}^{\mathbf{2}}\end{array}$ \\
\hline Danube $\mathbf{2 1}$ & $\mathbf{7 , 1 3 0}$ & $\mathbf{2 6 3}$ & $\mathbf{3 8}$ \\
\hline Bor County & 3,507 & 90 & 42 \\
\hline Zaječar County & 3,623 & 173 & 34 \\
\hline
\end{tabular}

Source: Estimation based on the data from 2002 Population Census in Serbia, P3C (2004).

According to 2011 data, the population density in Danube 21 Euro region in Serbia equaled overall 38 inhabit./ $\mathrm{km}^{2}$, whereas in Central Serbia the population density equaled nearly 100 inhab. $/ \mathrm{km}^{2}$. Population density in Danube 21 Euro region in Serbia was in a slight increase until the 1981, since when it is in constant decline, and the sharpest decline was recorded in the first decade of 21th century. In the 1948 the population density in Danube 21 Euro region was almost twice as low when compared with the population density in Central Serbia, though as the population growth was faster in Central Serbia, the difference between them was being constantly deepened.

Table 8 - Population densities in Danube 21 Euro region, according to County/NUTS3 by municipalities and areas, as well as in Central Serbia for the period of 1948-2011

\begin{tabular}{|l|c|c|c|c|c|c|c|c|}
\hline & $\mathbf{1 9 4 8}$ & $\mathbf{1 9 5 3}$ & $\mathbf{1 9 6 1}$ & $\mathbf{1 9 7 1}$ & $\mathbf{1 9 8 1}$ & $\mathbf{1 9 9 1}$ & $\mathbf{2 0 0 2}$ & $\mathbf{2 0 1 1}$ \\
\hline Central Serbia & $\mathbf{7 4 . 2}$ & $\mathbf{7 9 . 7}$ & $\mathbf{8 6 . 2}$ & $\mathbf{9 3 . 8}$ & $\mathbf{1 0 1 . 7}$ & $\mathbf{1 0 3 . 8}$ & $\mathbf{9 7 . 7}$ & $\mathbf{9 9 . 5}$ \\
\hline Danube21 & $\mathbf{4 3 . 0}$ & $\mathbf{4 5 . 0}$ & $\mathbf{4 6 . 5}$ & $\mathbf{4 8 . 3}$ & $\mathbf{4 8 . 7}$ & $\mathbf{4 4}$ & $\mathbf{3 9 . 4}$ & $\mathbf{3 3 . 9}$ \\
\hline Bor County & 40.4 & 42.8 & 45.1 & 50.3 & 51.6 & 46.7 & 42.0 & 35.9 \\
\hline Zaječar County & 46.5 & 47.6 & 47.9 & 46.4 & 45.8 & 41.3 & 36.8 & 32.0 \\
\hline
\end{tabular}

Source: Estimation based on the data from 2002 and 2011 Population Census in Serbia, P3C (2004), P3C (2011). 


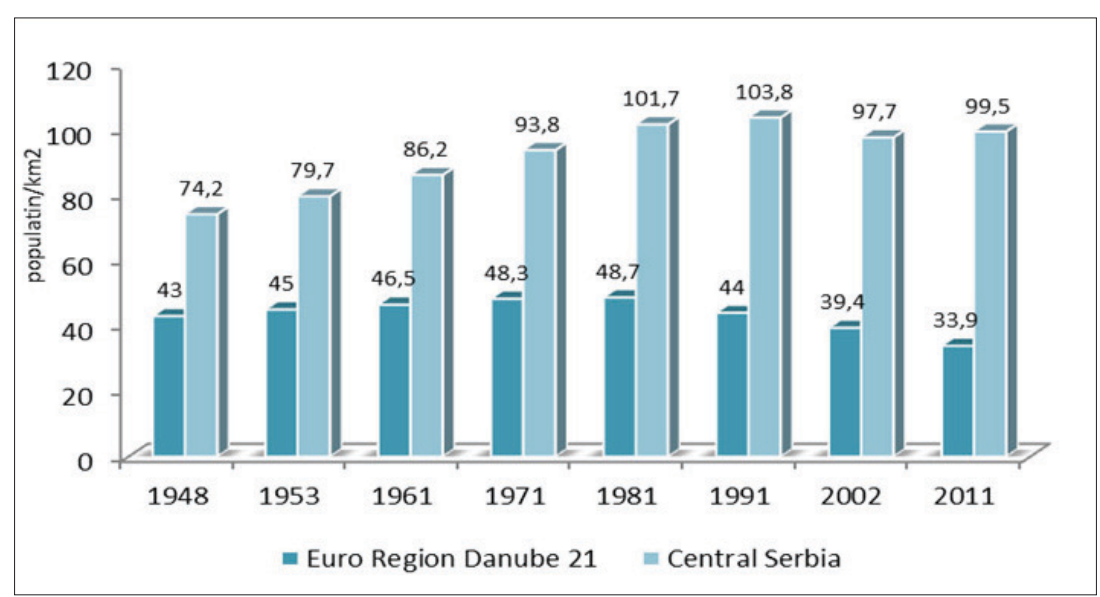

Figure 4 - Population density in Danube 21 Euro region and Central Serbia, 1948-2011

On the basis of data on population distribution by the settlement type during the period from The Second World War up to the present day, we can conclude that the urbanization process in Danube 21 Euro region has been going more slowly when compared to the urbanization in Central Serbia thereby the difference in shares of urban population insignificantly dropped. Soon after The Second World War the difference equaled overall about $4 \%$ in favor of Central Serbia, whereas according to the results from the last conducted 2011 Census it equalled about 3\%.

Table 9 - Trend in shares of urban population in Danube 21 Euroregion and Central Serbia for the period of 1948-2011

\begin{tabular}{|l|c|c|c|c|c|c|c|c|}
\hline & $\mathbf{1 9 4 8}$ & $\mathbf{1 9 5 3}$ & $\mathbf{1 9 6 1}$ & $\mathbf{1 9 7 1}$ & $\mathbf{1 9 8 1}$ & $\mathbf{1 9 9 1}$ & $\mathbf{2 0 0 2}$ & $\mathbf{2 0 1 1}$ \\
\hline Central Serbia & $\mathbf{2 0}$ & $\mathbf{2 1}$ & $\mathbf{2 8}$ & $\mathbf{4 1}$ & $\mathbf{4 8}$ & $\mathbf{5 4}$ & $\mathbf{5 6}$ & $\mathbf{5 6}$ \\
\hline Dunav 21 & $\mathbf{1 6}$ & $\mathbf{1 8}$ & $\mathbf{2 1}$ & $\mathbf{3 0}$ & $\mathbf{3 8}$ & $\mathbf{4 6}$ & $\mathbf{5 0}$ & $\mathbf{5 3}$ \\
\hline Bor County & 19 & 21 & 25 & 35 & 41 & 49 & 53 & 54 \\
\hline Zaječar County & 13 & 15 & 18 & 25 & 34 & 42 & 47 & 52 \\
\hline
\end{tabular}

Source: Estimation based on the data from 2002 and 2011 Population Census in Serbia, P3C (2004), P3C (2011). 


\section{Age structure and indicators of demographic ageing}

The role of inherited low fertility contributed to constant decrease in young population share considering all generations, with, at the same time, the increase in old population contingent. The process of demographic ageing for the period of 1981-2011 is particularly visible in relation to the reduction of the age pyramid base, as well as the sharp decrease in share of the population aged 25-34, thereby we highlight that this age group of female population represents the most important part of so-called "optimal fertility contingent". Women from optimal fertility contingent in Danube 21 Euro region in the 1981 represented $27.2 \%$ of the total number of women, and thirty years later this share has become twice as small, that is, in the 2011 it equalled 15\%. During the observed period it occurred the decrease in all categories shares of both the young and middle-aged population on one side, and the significant increase in shares of population older than 65 on the other side, which implies general conclusion about further movement ahead of the processes of biological depopulation and demographic population ageing in Danube 21 Euro region.

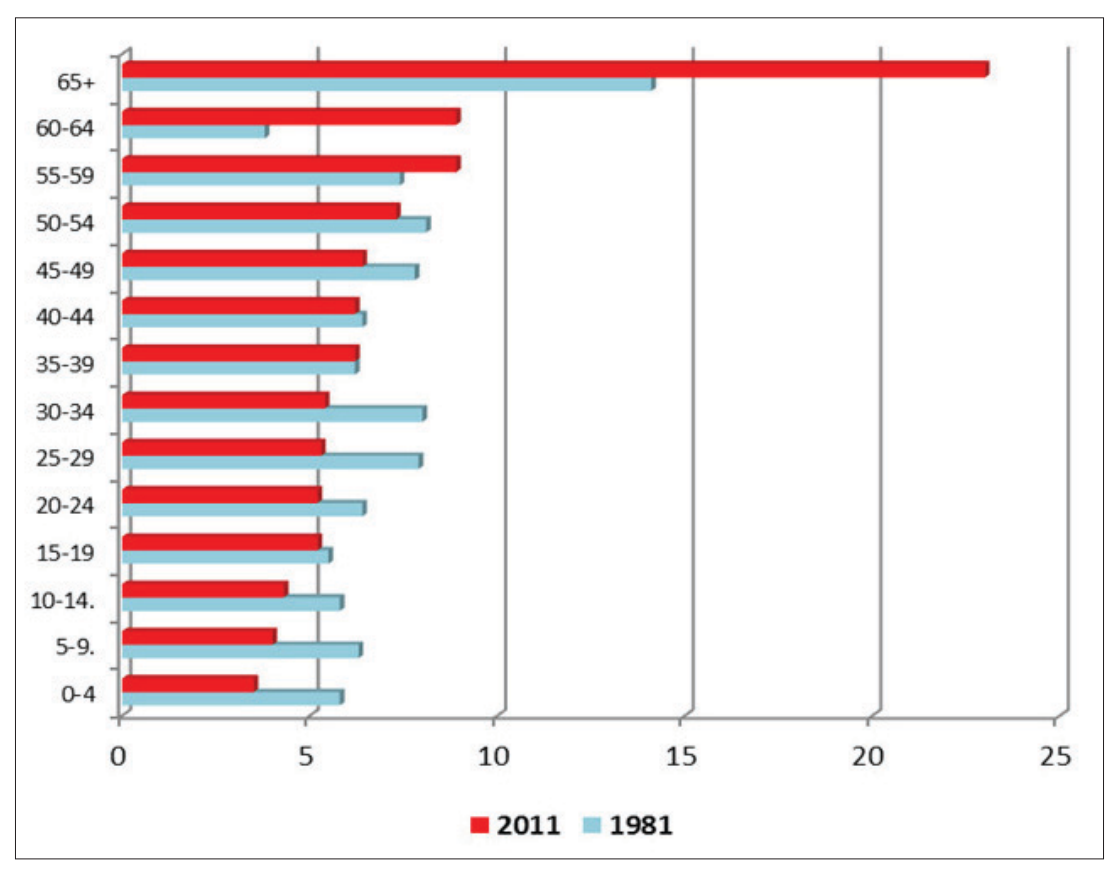

Figure 5 - The share of five-year age groups in total population of Danube 21 Euro region, 1981. and 2011. Source: Books of 1981 and 2011 population census 
The demographic ageing process is shown as well by the existent values of the other important indicators such as the average age and ageing index. The values of these indicators in 2011 indicate that the process of demographic population ageing in Danube 21 Euro region started earlier in relation to the population of Central Serbia, and the distribution of indicators by areas indicates the intensive process of demographic ageing in Zaječar area where the ageing index achieved the value above 2 which implies the profound demographic erosion for which it is difficult to find effective model of simulative population politics even in the conditions of its current application.

Table 10 - Indicators of demographic ageing of population in Danube 21 Euro region in 2011

\begin{tabular}{|l|c|c|c|c|c|}
\hline & Average age & $\mathbf{0 - 1 9}$ & $\mathbf{2 0 - 5 9}$ & $\mathbf{6 0 +}$ & Age index \\
\hline Central Serbia & $\mathbf{4 2 . 2}$ & $\mathbf{1 9 . 8}$ & $\mathbf{5 5 . 0}$ & $\mathbf{2 5 . 2}$ & $\mathbf{1 . 3}$ \\
\hline Danube 21 & $\mathbf{4 6 . 1}$ & $\mathbf{1 7 . 1}$ & $\mathbf{5 0 . 1}$ & $\mathbf{3 1 . 9}$ & $\mathbf{1 . 9}$ \\
\hline Bor County & 45.0 & 17.8 & 52.4 & 29.7 & 1.7 \\
\hline Zaječar County & 47.1 & 16.3 & 49.5 & 34.1 & 2.1 \\
\hline
\end{tabular}

Source: P3C (2014a).

The Natural Increase and Total Fertility Rate

The contemporary changes in natural increase of population in Danube 21 Euro region we are observing in the period of 1961-2010 and the data on natality and mortality indicate several conclusions.

The crude birth rate in the observed period decreased with about 51\%, whereas the highest value of $14.1 \%$ o was in the 1969 , and the lowest of $6.8 \%$ o in the 2010. Until the mid seventies of $20^{\text {th }}$ century the crude birth rate slightly varied from $12 \%$ o to $13 \%$, whereas since the 1977 to the present day has been in constant decline, therefore at the end of observed period in 2010 had lower value in relation to the total population of Central Serbia.

Trend in crude mortality rate in the area of Danube 21 Euro region had the opposite direction when compared with the trend in crude natality rate. The value of crude mortality rate in the observed period had been linearly increasing, while in 2010 reached the level of $19.7 \%$. 
The crude natural increase rate of population in the area of Danube 21 Euro region was positive by concluding the year 1979 (with the exception of the 1964 when it equalled $-0.1 \%$ ), and since the 1980 it has had the constant negative values, much earlier than in other parts of Republic of Serbia. As expected, the lowest value of crude natural increase rate was recorded in 2010 when it equalled $-12.9 \%$. In the same year crude natural increase rate in Central Serbia equalled $-4.8 \%$.

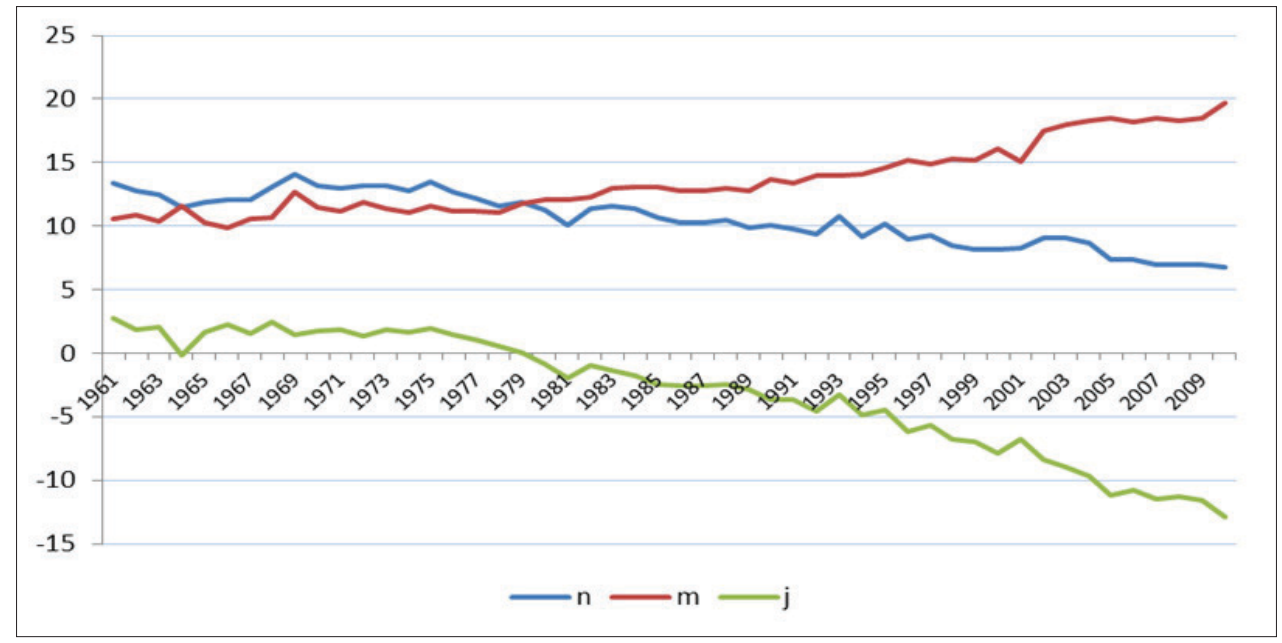

Figure 6 - Crude natality, mortality and natural increase rates in Danube 21 Euro region for the period of 1960-2010

The average ten-year period values of population natural increase in Danube 21 Euro region in the period of 1961-2010 show the apparition of biological depopulation already since the eighties, and the same trend has been lasting up to present day. In the first decade of 21th century the average value of natural increase rate equalled $-10.4 \%$ which is the result of considerably high mortality values caused by unfavourable age structure of population and long-lasting process of demographic ageing. 
Table 11 - Average ten-year values of crude natality rates (n), mortality rates $(m)$ and natural increase rates (j) of population in Danube 21 Euro region for the period of 1961-2010.

\begin{tabular}{|c|c|c|c|}
\hline & $\mathbf{n}$ & $\mathbf{m}$ & $\mathbf{J}$ \\
\hline $1961-70$ & 12.6 & 10.9 & 1.7 \\
\hline $1971-80$ & 12.5 & 11.4 & 1.1 \\
\hline $1981-90$ & 10.6 & 12.9 & -2.3 \\
\hline $1991-2000$ & 9.2 & 14.7 & -5.5 \\
\hline $2001-2010$ & 7.7 & 18.1 & -10.4 \\
\hline
\end{tabular}

Source: Natural increase of population in the Republic of Serbia 1961-2010-data by municipalities, SORS, Belgrade, 1-251.

Table. 12 - Total fertility rates in Danube 21 Euroregion, by municipalities, 2006-2008.

\begin{tabular}{|l|l|}
\hline Republic of Serbia & $\mathbf{1 . 4 0}$ \\
\hline Danube 21 & $\mathbf{1 . 2 9}$ \\
\hline Bor County & 1.25 \\
\hline Zajecar County & 1.33 \\
\hline
\end{tabular}

Source: Calculation based on estimates (Rasević, Penev, 2009, 129)

\section{Discussion and conclusion}

Today, accessibility is recognized, by planners and other technicians, as a crucial variable for territorial development of cross border areas. The paper evaluates and, assesses the accessibility levels and demography pattern of Euro region Danube 21.

Existing accessibility pattern clearly indicates the differences between central and peripheral regions. Within the Euro region Danube 21 in Serbia the low accessibility levels represent the consequence of lower development of the road and railway transport than in central ones. Even though it exists the road network of different classes, state highway network of I class still is not properly developed so it is necessary its modernization and reconstruction. As for the local roads, over $50 \%$ is unpaved. There is not one highway running through Bor County.

Accordingly the National Spatial Plan of the Republic of Serbia the corridor is reserved for planned motorway from Nis to Zaječar, as well as the potential branch construction to Vidin and to Corridor IV in the Republic of 
Bulgaria. It is also planned both the modernization of existing roads and the construction of bypass roads around the county centers, Zaječar and Bor.

Both the rehabilitation and the modernization of existing single-track railways, which run through the territory of Timok Region, will be reflected in accessibility of this region. It is planned the construction of transport infrastructure through the reconstruction of the existing railway tracks on the route Nis - Zaječar - Prahovo, Nis - Makedonija, etc., with branches in Romania and Bulgaria, and through building the $\mathrm{E} 85$ high-speed railway. Possible development of railway infrastructure has the potential to advance both the road communication between populated places and the touristic accessibility of the region. Expected reconstruction and modernization of the single-track railways is of great significance due to planned construction of the linking between the port "Prahovo" on the Danube River and the Republic of Romania across the dam Iron Gate II in the future. This way the railways in Euro region Danube 21, in the first place in Bor County, could be characterized as the railways of international significance.

From the standpoint of internal integration objectives, of a particular importance is the improvement of the regional and local road network towards insufficiently activated parts of region and the linking of that network with longitudinally and transversal motorway corridors, that is, with highway.

In order to achieve the bigger territorial cohesion and the regional sustainability, the following problems within the Euro region Danube 21 as well:

- Depopulation and negative demographic trends, as well as the economic stagnation and the regression in rural regions; significantly polarised character of urbanization - the regional development unbalance; insufficient trans municipality/ trans regional cooperation upon the development activities planning - horizontal disagreement;

- Not exploited the comparative advantage of proximity of main infrastructure systems in corridor, which could stimulate affect immigration from other regions of Serbia and more even population distribution within the subject area;

- Insufficient quality of the transport network as well as the small number of entrances/exits on the routes in particular parts of Euro region;

- Low level of equipment with transport, utility and community infrastructure in villages; low level of urbanization and high proportion of municipalities with dominant rural character. 
The increase of accessibility level ought to be accomplished through the rational development, modernization and rehabilitation of local routes which provide the connection throughout the settlements within functional urban regions, through strengthening the route connections as well as through the increase of both transport and communication accessibility of less developed, peripheral and sparsely populated districts;

According to the proposed strategic priorities and transport development planning solutions in National Spatial Plan of Serbia, the most important positive effects concerning the accessibility increase ought to be expected in the area of Euro region, to which belong the districts with the lowest accessibility levels.

Thereby, we must not neglect the fact that in the subject area of Danube 21 Euro region the reasons for district inaccessibility could be as well the significant deviations of executed, in comparison with the planning solutions and planned investments, due to high construction prices, which at the same time provide low refund rates, earlier invested, in the main, due to low population densities.

Analysis of the final accessibility results with recently planned solutions for the sustainable transport at national level, according to the National Spatial Plan of the Republic of Serbia, shows that that these border problems associated with measures of accessibility in the most peripheral county of Bor and Zaječar (Euro region Danube 21) should become less severe, but they would not disappear. That is strong related with demographic pattern in this area, because depopulation process. The sharp decline in population in Euro region Danube 21 over the second half of the 20th century seems to be a consequence of the long-term decline in both the natality and the natural increase, which started at the end of 19th and the beginning of 20th century (Knežević 2013). The dynamics of spatial population redistribution for the period of 1948-2011 is characterized by spatial-demographic polarization into urban areas with the continuous population increase, the rural areas of demographic stagnation and the population decrease in other settlements.

Unfavourable age structure of population is the result of long-term decline in fertility (demographic inertia) and its remaining at very low level. At the same time with this trend, the shares of young population were going down, and one of the main reasons for the current negative trend in reproduction is the entrance into the reproduction stage of age cohorts which resulted from the period of low natality. On the age structure of population, 
to the middle of 20th century, had a significant impact the mortality trend of population (the changes in mortality distribution by age) on one side, and the migration processes from the period of after war industrialism and urbanization (Knežević, Đurđev, Arsenović 2014).

Demographic changes which have encompassed the area of Euro region Danube 21 over the period of 19th and the beginning of 20th century are by its main characteristics specific, but at the same time predictable, and the consequences of the depopulation processes are denoted by all indicators of population dynamics and imply the total demographic erosion in this area which is not possible to be repaired not even with the most radical instruments of population and transport politics.

\section{References}

Breznik, D. (1988). Demografija - analiza, metodi i modeli. Naučna knjiga, Beograd.

Boehnke, K., Rippl, S., and Fuss, D. (2015). Sustainable Civil-Society Engagement: Potencials of a Transnational Civil Society in French-German, Polish-German, and Czech-German Border Regions. Sustainability Journal, 7. 4078-4099.

Bufon, M. (2011). “Ne vrag, le sosed bo mejak!”. Koper. 1-281.

Castanho, R., Loures, L., Fernández, J. and Pozo, L. (2016). Identifying critical factors for success in Cross Border Cooperation (CBC) development projects. Habitat International, doi.org/10.1016/j.habitatint.2016.10.004.

Castanho, A., Vulevic, A., Fernández, J., Pozo, L., Loures, l., Gómez, J. (2017). Accessibility and connectivity - Movement between Cities, as a Critical Factor to Achieve Success on Cross-Border Cooperation (CBC) Projects. A European Analysis.

Commission of the European Communities 2001: White Paper on European Transport Policy for 2010: a time to decide, COM (2001) 370 final, Brussels

Commission of the European Communities 2005: Trans-European Transport Network. TEN-T Priority axes and projects (2005). Luxembourg.

Commission of the European Communities 2006: Keep Europe moving. Sustainable mobility for our continent, Mid-term review of the European Commission's 2001 Transport White Paper. COM (2006) 314 final. Brussels. 
Commission of the European Communities 2008: Green Paper on Territorial Cohesion: Turning territorial diversity into strength. COM (2008) 616 final. Brussels

Commission of the European Communities (2009). Panorama of Transport. Eurostat Statistical books. Luxembourg.

Domínguez, J. A., Noronha Vaz, T., \& Vaz, E. (2015). Sustainability in the trans-border regions? The case of Adalusia - Algarve. Int. J. Global Environmental Issues, Vol. 14, Nos. 1/2, pp. 151-163.

Dominguez Castro, L., \& Varela Alvarez, E. (2015). Building Europolis on the Basis of Local "Informal" Cooperation in European Cross-Border Spaces: The Case of RIET. Geopolitical Magazine - Studies of Space and Power. Volume: 6 Issue: 2 Pages: 225-246.

Dulic, O. (Minister), Stojkov, B. (2010). National Spatial Plan of the Republic of Serbia 2010-2014-2020. Abridged version. Belgrade.

European Commission ESDP - European Spatial Development Perspective (1999). Towards balanced and sustainable development of the territory of the European Union, Office for Official Publications of the European Communities. Luxembourg.

European Spatial Planning Observation Network ESPON (2010-2014). Transport accessibility at regional/local scale and patterns in Europe. TRACC. Luxembourg. Internet: http://www.spiekermann-wegener.com/pro/pro1_e.htm

ESPON Project Demographic and migratory flows affecting European regions and cities (2008-2010)

ESPON 2009: Trends in accessibility. Territorial observation no. 2. Luxembourg.

ESPON - ITAN - Integrated Territorial Analysis of the Neighborhood. (2015).

ESPON 2010-2014: Transport accessibility at regional/local scale and patterns in Europe. ESPON TRACC. Luxembourg. Internet: http://www.spiekermann-wegener.com/pro/pro1_e.htm

ESPON Trends in Accessibility. (2013).

ESPON 2002-2005. Territorial Development and Cohesion - ESPON projects 2.1.1. Territorial Impacts of EU Transport and TEN Policies. Luxembourg. Internet: http:/ / www.espon.eu/main/

ESPON. (2002-2005). Territorial Development and Cohesion. ESPON projects 1.2.1. Transport Services and Networks. Luxembourg. Internet: http://www.espon.eu/main/ 
ESPON Paper (2017). Revealing territorial potentials and shaping new policies in specific types of territories in Europe Islands, mountains, sparsely populated and coastal regions.

First ESPON Synthesis Report. (2013). New Evidence on Smart. Sustainable and Inclusive Territories. Luxembourg.

ESPON ULYSSES (2013). Using applied research results from ESPON as a yardstick for cross-border spatial development planning.

Gastner, M. T., Newman, M. E. J. (2006). The spatial structure of networks. The European Physical Journal B, 49(2), 247-252. DOI: 10.1140/epjb/e2006-00046-8

Handy, S., Niemeier, D.(1997). Measuring accessibility: an exploration of issues and alternatives. Environment and Planning A, 29, 1175-1194. doi:10.1068/a291175

Ingram, D. (1971). The concept of accessibility: a search for an operational form. Regional Studies, 5, 101-107. DOI:10.1080/09595237100185131

Knezevic, A. (2013). Historical-Demographic and Ethno demographic Basis of the Demographic Development in East Serbia. Doctoral Dissertation, University of Belgrade-Faculty of Geography. Belgrade 1-277. UDC 911.3:314.04(497.11).

Knezevic, A. (2014). Methodological issues of demographic analysis: The reconciliation of census data and vital statistics with administrative - territorial changes (Case Study of Eastern Serbia). Demography, Vol. XI. University of Belgrade, Faculty of Geography, 53-77. Belgrade. UDC 314.116/.117(497.11-11)"18/20

Knezevic, A., Đurđev, B., Arsenović, D. (2014). The demographic potentials of Euro region Danube XXI in Serbia-Consequences of biological depopulation and population ageing. The Third Romanian-Bulgarian-HungarianSerbian Conference. Geographical Research and Cross-Border Cooperation within the Lower Basin of the Danube. Belgrade-Novi Sad, 1-123.

Knezevic, A., Vojkovic, G. (2015). Spatial extent in demographic researchApproach and problems. Bulletin of the Serbian Geographical Society, Vol. XCV (2). Belgrade, Serbian Geographical Society, 1-24. Belgrade. DOI 10.2298/GSGD160112001K

Kotavaara, O., Antikainen, H. and Rusanen, J. (2011a). Population change and accessibility by road and rail network: GIS and statistical approach to Finland 1970-2007. Journal of Transport Geography, 19(4), 926-935. DOI: http://dx.doi.org/10.1016/j.jtrangeo.2010.10.013 
Kotavaara, O., Antikainen, H., Rusanen, J. (2011b). Urbanization and transportation in Finland, 1880-1970. Journal of Interdisciplinary History, 42(1), 89-109. http://dx.doi.org/10.1162/JINH_a_00206

Kurowska-Pysz, J. (2016). Opportunities for Cross-Border Entrepreneurship Development in a Cluster Model Exemplified by the Polish-Czech Border Region. Sustainability Journal 2016, 8, 230; doi:10.3390.

LISER, (2015). Opportunities of cross-border cooperation between small and medium cities in Europe. Report written in the scope of the Observatory of Territorial Development, in partnership with the Department of Spatial Planning and Development - Ministry of Sustainable Development and Infrastructure, Luxembourg Institute of Socio - Economic Research. Luxembourg.

Lösch , A. (1994). Die Räumliche Ordnung der Wirtschaft, Secund edition. Stuttgart

Mun, S. (1997). Transport network and system of cities. Journal of Urban Economics, 42(2), 205-221.

Nicolini, E. \& Pinto, M. (2013). Strategic Vision of a Euro-Mediterranean Port City: A Case Study of Palermo. Sustainability Journal 2013, 5, 3941-3959.

Pitsiava, M. (2007). Transport infrastructure priorities and territorial cohesion prospects in SE Europe. Chapter 9. Overcoming Fragmentation in Southeast Europe. Spatial Development Trends and Integration Potential. Ashgate: Urban and Regional Planning and Development Series

Rašević, M., Penev, G. (2009). Opštine Republike Srbije. Osnovni demografski, ekonomski i socijalni pokazatelji relevantni za populacionu politiku. Društvo demografa Srbije, Beograd, 431 str.

Statistical Office of the Republic of Serbia. (2012). Natural changes of population in the Republic of Serbia from 1961 to 2010-Data by municipalities. Belgrade. 1-251. ISBN 978-86-6161-019-6.

Statistical Office of the Republic of Serbia and Federal Statistical Office, 19502011: Demographic Statistics. Belgrade.

Tosic, B., Stojanovic, B., Miletić, R. (2005). Population-functional processes at the settlements and centers. Example of Euroregion Danube XXI in Serbia. The Bulletin of the Serbian Geographical Society, vol LXXXV-No.1. Belgrade. Internet: http:/ / www.doiserbia.nb.rs/img/doi/0350-3593/2005/0350-35930501149T.pdf

van Houtum,H. (2000). Introduction: Current issues and Debates on borders and Border Regions in European Regional Science in M. Velde and h. van Houtum. Border, regions and People. European research in regional Science. No.10. Pion. London. 
Vickerman, R. (1995). Location, accessibility and economic development: The appraisal of transeuropean networks. Transport Policy, 2(4), 225-234.

Vickerman, R., Spiekermann, K., Wegener, M. (1997). Accessibility and economic development in Europe, Regional Studies, Vol. 33.1, pp. 1-15

Vlahovic, P. (2006). Serbia - country, people, life, customs. Belgrade.

Vulevic, A. (2013). Infrastructural Corridors and their Influence on Spatial Development Example Corridor VII in Serbia. Doctoral dissertation. University of Belgrade - Faculty of Geog raphy, Serbia 14601.

Vulević, A. (2016). Linkage between Regional Accessibility, Economic Development, and Logistic Infrastructure. In T. Kramberger,V. Potočan and V. M. Ipavec, editor, Sustainable Logistics and Strategic Transportation Planning. DOI:10.4018/978-1-5225-0001-8.ch012

Vulevic, A. (2016). Accessibility concepts and indicators in transportation strategic planning issues: theoretical framework and literature review', Logistics $\mathcal{E}$ Sustainable Transport, Volume 7, Issue 1, Pages 58-67, ISSN (Online) 2232-4968, DOI: 10.1515/jlst-2016-0006.

РЗС (2004). Попис становништва, домаћинстава и станова 2002. у Републиии Србији. Къ. 9, Упоредни преглед броја становника 1948, 1953, 1961, 1971, 1981, 1991. и 2002. Београд: Републички завод за статистику (РЗС).

РЗС (2011). Попис становништва, домаћинстава и станова у Републиии Србији 2011. - први резултати. Београд: Републички завод за статистику (РЗС).

РЗС (2014а). Попис становништва, домаћинстава и станова 2011. у Републиuзи Србији. Къ. 2, Старост и пол. Београд: Републички завод за статистику (РЗС).

РЗС (2014б). Попис становништва, домаћинстава и станова 2011. у Републици Србији. Књ. 20, Упоредни преглед броја становника 1948-2011. Београд: Републички завод за статистику (РЗС). 